\title{
Early and late genetic changes in clear cell renal carcinoma
}

$\mathbf{R}_{c}$ somal alterations during tumor progression $[1,2]$. Chromosome $3 p$ deletions are known to occur early in carcinogenesis. However, the nature of subsequent events, their interrelationships, and sequence are poorly understood, as one usually only obtains a single "view" of the dynamic process of tumor development in a particular cancer patient. To address this limitation, we used comparative genomic hybridization (CGH) analysis in combination with a distance-based and a branching tree method to search for tree models of the oncogenesis process of 116 conventional (clear cell) renal carcinomas $[3,4$, 5]. This provides a means to analyze and model cancer development processes in a more dynamic fashion, including the presence of multiple pathways, as compared to the fixed linear model first proposed by Vogelstein et al. in 1988 for colorectal cancer. The most common DNA losses involved 3p (61\%), 4q (50\%), 6q (40\%), $9 p(35 \%), 13 q$ (37\%), and Xq (21\%). The most common gains were seen at chromosome $17 \mathrm{p}$ and $17 \mathrm{q}$ (20\%). The tree model derived from the distance-based method is consistent with the established theory that $-3 p$ is an important early event in conventional (clear cell) renal cancer and supports the prediction made from the branching tree method that $-4 \mathrm{q}$ is another important early event. Both tree models suggest that there may be two groups of clear cell renal cancers: one character- ized by $-6 \mathrm{q},+17 \mathrm{q}$, and $+17 \mathrm{p}$, and another by $-9 p,-13 q$, and $-18 q$. Putative prognostic parameters were -9p and -13q. The distance-based tree clarifies that $-8 \mathrm{p}$ (present in $12 \%$ of tumors) is a late event, largely independent of other events. In summary, tree modeling of CGH data provided new information on the inter-relationships of genetic changes in renal cancer, their possible order, as well as a clustering of these events. Using tree analysis, one can derive a more in-depth understanding of the renal cancer development process than is possible by simply focusing on the frequencies of genetic events in a given cancer type.

\section{Corresponding author Prof.Dr. Holger Moch}

Institut für Pathologie, Schönbeinstr.

40, 4056 Basel, Schweiz

e-mail:hmoch@uhbs.ch

Conflict of interest: No information supplied.

\section{References}

1. Presti JC Jr, Moch H, Gelb AB, Huynh D, Waldman FM (1998) Initiating genetic events in small renal neoplasms detected by comparative genomic hybridization. J Urol 160:1557-1561

2. Moch H, Presti JC Jr, Sauter G, Buchholz N, Jordan P, Mihatsch MJ, Waldman FM (1996) Genetic aberrations detected by comparative genomic hybridization are associated with clinical outcome in renal cell carcinoma. Cancer Res 56:27-30

3. Desper R, Jiang F, Kallioniemi OP, Moch H, Papadimitriou CH, Schäffer AA (1999) Inferring tree models for oncogenesis from comparative genome hybridization data. J Comput Biol 6:37-51
4. Desper R, Jiang F, Kallioniemi OP, Moch $\mathrm{H}$, Papadimitriou CH, Schäffer, AA (2000) Distance-based reconstruction of tree models for oncogenesis. J Comput Bio 7:789-803

5. Jiang F, Desper R, Papadimitriou CH, Schäffer AA, Kallioniemi OP, Richter J, Schraml P, Sauter G, Mihatsch MJ, Moch H (2000) Construction of evolutionary tree models for renal cell carcinoma from comparative genomic hybridization data. Cancer Res 60:6503-6509 